\title{
Increases in platelet and red cell counts, blood viscosity, and arterial pressure during mild surface cooling: factors in mortality from coronary and cerebral thrombosis in winter
}

\author{
W R KEATINGE， S R K COLESHAW，F COTTER， M MATTOCK， M MURPHY， R CHELLIAH
}

\begin{abstract}
Six hours of mild surface cooling in moving air at $24^{\circ} \mathrm{C}$ with little fall in core temperature $\left(0 \cdot 4^{\circ} \mathrm{C}\right)$ increased the packed cell volume by $7 \%$ and increased the platelet count and usually the mean platelet volume to produce a $15 \%$ increase in the fraction of plasma volume occupied by platelets. Little of these increases occurred in the first hour. Whole blood viscosity increased by $21 \%$; plasma viscosity usually increased, and arterial pressure rose on average from $126 / 69$ to $138 / 87 \mathrm{~mm} \mathrm{Hg}$. Plasma cholesterol concentration increased, in both high and low density lipoprotein fractions, but values of total lipoprotein and lipoprotein fractions were unchanged.

The increases in platelets, red cells, and viscosity associated with normal thermoregulatory adjustments to mild surface cooling provide a probable explanation for rapid increases in coronary and cerebral thrombosis in cold weather. The raised arterial pressure and possibly cholesterol concentration may contribute to slower components of the increased thrombosis.
\end{abstract}

\footnotetext{
Department of Physiology, The London Hospital Medical College, London E1 2AD

W R KEATINGE, MB, PHD, professor

S R K COLESHAW, BSC, research scientist

M MURPHY, BSC, laboratory scientific officer

Department of Haematology, The London Hospital, London E3 4LL F COTTER, MB, MRCP, lecturer

Department of Medicine, Guy's Hospital, London SE1 9RT

M B MATTOCK, MSC, PHD, senior biochemist

R CHELLIAH, PHD, postdoctoral research assistant

Correspondence to: Professor W R Keatinge.
}

\section{Introduction}

The death rate from coronary and cerebral thrombosis in England and Wales rises linearly as air temperature falls; daily deaths per million increase from 4.9 to 6.9 (myocardial infarction) and from 3.2 to 4.8 (strokes) when the minimum daily temperature falls from $17^{\circ}$ to $-5^{\circ} \mathrm{C} .{ }^{1}$ Cold related mortality from these causes is thus very large compared with that from hypothermia, which accounts for 0.016 daily deaths per million (1981 figures of the Office of Population Censuses and Surveys (Mortality Statistics)). The explanation for cold related thrombosis has been uncertain. Small falls in plasma antithrombin III $^{2}$ and increases in arterial blood pressure ${ }^{3-5}$ have been reported in cold weather; but the falls in antithrombin were offset by increases in fibrinolytic activity, ${ }^{26}$ and it was noted that the increases in arterial pressure could not readily explain the increases in mortality, which largely occur within the first few days after a low air temperature. Increased packed cell volume has been observed during exposure to $\operatorname{cold}^{7}{ }^{8}$ but does not appear to have been associated with possible adverse effects.

Since platelet aggregation causes the initial stage of arterial thrombosis, ${ }^{9}$ we have measured changes in platelets as well as in red and white blood cells and blood viscosity in people exposed to cold. We have also measured cholesterol and triglyceride concentrations in plasma and in different lipoprotein fractions and plasma concentrations of thromboxane $B_{2}$ a breakdown product of the shortlived thromboxane $A_{2}$ which promotes platelet aggregation. Arterial pressure and other cardiovascular and metabolic responses that might have a bearing on cold related mortality were monitored.

\section{Subjects and methods}

The subjects were four male and four female student volunteers, aged $18-25$, who were healthy and not taking medications. Mean subcutaneous fat thickness was estimated from ultrasonic readings at four sites, ${ }^{10}$ and surface area was calculated from height and weight. ${ }^{11}$ Two subjects were studied at a time; each pair was studied twice after sleeping overnight in the laboratory in still air at $24 \pm 1^{\circ} \mathrm{C}$ with bedclothes. At 0700 they ate a fat free meal of two pieces of toast 
with jam and $200 \mathrm{ml}$ unsweetened orange juice. Control measurements were made and an initial sample of blood taken. At 0900 one subject was cooled for six hours on a net bed by rapid air movement at approximately $10 \mathrm{~m} / \mathrm{s}$, wearing only a shortsleeved cotton shirt, shorts, and underwear. The other (control) subject lay on a couch for the same time with the same clothing but with two blankets and in still air. Both subjects were recumbent and in air at $24 \pm 1^{\circ} \mathrm{C}$ throughout. A 28 watt electrical heating pad was applied to the arm used for blood sampling to ensure free flow of blood. The subjects ate another, similar meal at 1300 and the experiment ended at 1500 . In the second experiment, 48 hours later, the subject cooled in the first experiment was the control, and the control subject of the first experiment was cooled.

Skin temperature was measured by uncovered 28 gauge copper constantan thermocouples held on the skin by tension, and rectal temperature by a thermistor probe (Light Laboratories) inserted $120 \mathrm{~mm}$. Metabolic rate was calculated ${ }^{12}$ from the oxygen deficit and volume of expired gas collected by a mouthpiece and valve assembly, and cardiac output was estimated by the single breath method, ${ }^{13}$ carbon dioxide and oxygen being measured at the mouthpiece by Beckman LB2 and OM11 analysers and volume by a pneumotachygraph. An online computer (Apple 2) was used to process the results. The electrocardiogram was recorded from leads over the upper end of the sternum and the apex of the heart. Systolic and diastolic arterial blood pressures were measured by an automatic sphygmomanometer (Dinamap, Critikon).

Samples of flowing blood, totalling $95 \mathrm{ml}$ in a day's experiment, were taken from a flexible indwelling cannula (20 gauge, $31.8 \mathrm{~mm}$ long; Jelco) in the antecubital vein, fitted with an obturator to keep its lumen patent. No heparin was used. Thromboxane $B_{2}$ was measured by radioimmunoassay of plasma treated with edetic acid using antiserum provided by Seragen. Fibrinogen was assayed ${ }^{14}$ in citrated blood. Platelet and red cell counts and mean sizes were measured in edetic acid treated blood by a Coulter $S$ plus counter, and distribution of white cell types counted from samples of 100 cells in blood smears. Whole blocd viscosity and plasma viscosity were measured in edetic acid treated blood by the Wells-Brookfield cone and plate viscometer. ${ }^{15}$ Cholesterol and triglyceride concentrations were determined in edetic acid treated plasma and in lipoprotein fractions after ultracentrifugal separation of very low density lipoprotein $\left(<1006 \mathrm{~kg} / \mathrm{m}^{3}\right)$, low density lipoprotein (1006-1063 $\left.\mathrm{kg} / \mathrm{m}^{3}\right)$, and high density lipoprotein $\left(>1063 \mathrm{~kg} / \mathrm{m}^{3}\right)$ by the method of Carlson. ${ }^{16}$ Cholesterol and triglycerides were assayed by Technicon autoanalyser II enzymatic methods.

Statistical comparisons were by the paired $t$ test for small samples.

\section{Results}

The mean (SE) height of the eight subjects was $1.72(0.05) \mathrm{m}$, weight $63.9(6.4) \mathrm{kg}$, and subcutaneous fat thickness $7.6(1.0) \mathrm{mm}$.

Figure 1 shows that cooling by fast moving air at $24^{\circ} \mathrm{C}$ rapidly reduced skin temperature by about $5^{\circ} \mathrm{C}$ on the trunk and $7^{\circ} \mathrm{C}$ on the hands and calves, and caused a slow fall of $0.4^{\circ} \mathrm{C}$ in body core temperature. By comparison there was a small diurnal increase in control experiments. Metabolic rate did not rise significantly during the first 30 minutes of cooling, but then increased, with visible shivering in most subjects, to $37 \%$ above that in the control experiments at the end of six hours. This was accompanied by hyperventilation, shown by a fall in end tidal carbon dioxide pressure $\left(\mathrm{PCO}_{2}\right)$.
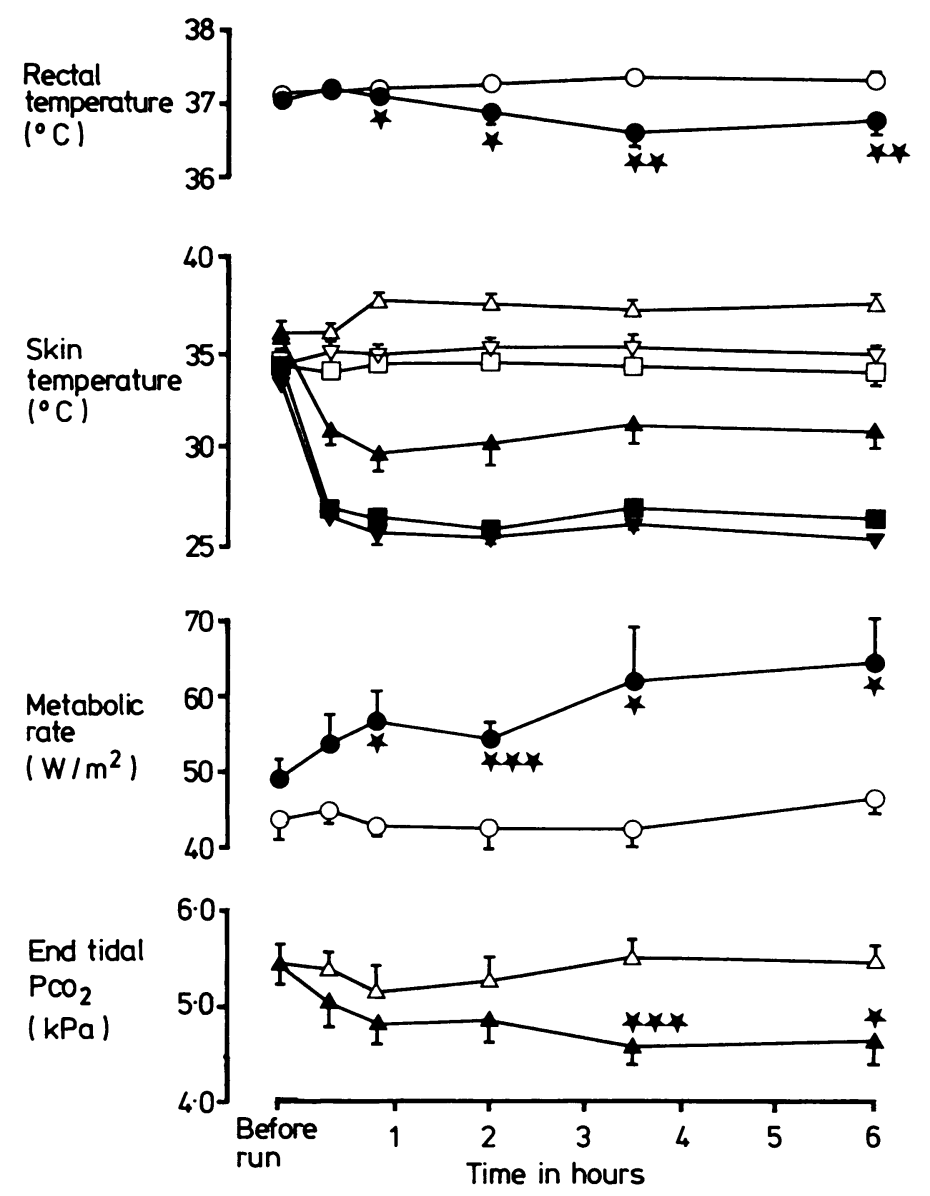

FIG 1-Temperature and metabolic and respiratory responses. Open symbols represent control run. Closed symbols represent cold run. Skin temperatures : trunk $(\triangle \boldsymbol{\Delta})$, hand $(\nabla \nabla)$, calf $([\boldsymbol{\square})$. Difference from control value: ${ }^{*} \mathrm{p}<0.05 ;{ }^{* *} \mathrm{p}<0.01 ;{ }^{* * *} \mathrm{p}<0.001$. All skin temperatures differed from control $(p<0.01)$ after start of cooling.

Conversion: SI to traditional units-End tidal $\mathrm{PCO}_{2}: 1 \mathrm{kPa} \approx 7.5 \mathrm{~mm} \mathrm{Hg}$.

Packed cell volume (table I) increased in the cold, on average by $7 \%$, due to an increase in numbers of red cells per unit volume of blood; red cell volume did not change significantly. The fraction of plasma volume occupied by platelets increased by an average of $15 \%$, largely due to an $8 \%$ increase in numbers of platelets per unit volume of blood with raised packed cell volume and reduced plasma fraction. Mean platelet volume also increased in the cold; the increase did not quite reach significance but occurred in six of the eight experiments. The number of neutrophil polymorphonuclear leucocytes per unit volume of blood increased in the cold and also, to a less extent, in control experiments. Little of the increase in platelet count, compared with control experiments, and only about a third of the increase in red cell numbers had occurred in the first hour in the cold. A tendency for red cell and platelet counts to decline in the first hour of control experiments may be explained in part by haemodilution after taking

TABLE I-Changes in blood cells and platelets. Values are means (SE in parentheses)

\begin{tabular}{|c|c|c|c|c|}
\hline & & Before experiment $(n=8)$ & Change during first hour $(n=6)$ & Change during six hours $(n=8)$ \\
\hline Red cell count ( $\times 10^{12} / 1$ blood $)$ & $\left\{\begin{array}{l}\text { Cold } \\
\text { Control }\end{array}\right.$ & $\begin{array}{ll}4.65 & (0 \cdot 23) \\
4.63 & (0 \cdot 15)\end{array}$ & $\begin{array}{ll}+0.11 & (0.06) \\
-0.15 & (0.05) \dagger\end{array}$ & $\begin{array}{l}+0.35(0.07)^{* *}+\dagger \\
-0.03(0.03)\end{array}$ \\
\hline Packed cell volume & $\left\{\begin{array}{l}\text { Cold } \\
\text { Control }\end{array}\right.$ & $\begin{array}{l}0.395(0.025) \\
0.391(0.017)\end{array}$ & $\begin{array}{l}+0.007(0.004) \\
-0.012(0.004) \dagger\end{array}$ & $\begin{array}{l}+0.029(0.005)^{* *}+++ \\
0.000(0.003)\end{array}$ \\
\hline Platelet count $\left(\times 10^{\%} / 1\right.$ blood $)$ & $\left\{\begin{array}{l}\text { Cold } \\
\text { Control }\end{array}\right.$ & $\begin{array}{l}291(27) \\
287(28)\end{array}$ & $\begin{array}{l}-10(4) \\
-15(5) \dagger\end{array}$ & $\begin{array}{l}+23(9) \dagger \\
+\quad 7(5)\end{array}$ \\
\hline Platelet volume (f) & $\left\{\begin{array}{l}\text { Cold } \\
\text { Control }\end{array}\right.$ & $\begin{array}{ll}8 \cdot 8 & (0.5) \\
8 \cdot 7 & (0.4)\end{array}$ & $\begin{array}{ll}0 \cdot 0 & (0 \cdot 2) \\
0 \cdot 0 & (0 \cdot 1)\end{array}$ & $\begin{aligned}+0.2 & (0.1) \\
0.0 & (0.1)\end{aligned}$ \\
\hline Platelets as fraction of plasma by volume $\left(\times 10^{-3}\right)$ & $\left\{\begin{array}{l}\text { Cold } \\
\text { Control }\end{array}\right.$ & $\begin{array}{ll}4 \cdot 12 & (0 \cdot 21) \\
4 \cdot 01 & (0 \cdot 22)\end{array}$ & $\begin{array}{ll}-0.07 & (0.11) \\
-0.23 & (0.07) \dagger\end{array}$ & $\begin{array}{l}+0.61 \quad(0.13)^{*}+\dagger \\
+0.12(0.11)\end{array}$ \\
\hline Neutrophil count $\left(\times 10^{\circ} / 1\right.$ blood $)$ & $\left\{\begin{array}{l}\text { Cold } \\
\text { Control }\end{array}\right.$ & $\begin{array}{ll}3.79 & (0.31) \\
3.45 & (0.33)\end{array}$ & $\begin{array}{ll}+0.42 & (0.28) \\
-0.17 & (0.06) \dagger\end{array}$ & $\begin{array}{ll}+2.04 & (0.47)^{*} \dagger \dagger \\
+0.74 & (0.29) \dagger\end{array}$ \\
\hline
\end{tabular}

Difference from control: $* p<0.05 ; * * p<0.01$

Difference from initial value: $t p<00 ; ;++p<0.01 ;+\dagger+p<0.001$. 
TABLE II-Changes in viscosity (mPas). Values are means ( $S E$ in parentheses)

\begin{tabular}{|c|c|c|c|c|}
\hline & & Before experiment $(n=8)$ & Change during first hour $(n=6)$ & Change during six hours $(n=8)$ \\
\hline Blood at shear rate $230 / \mathrm{s}$ & $\left\{\begin{array}{l}\text { Cold } \\
\text { Control }\end{array}\right.$ & $\begin{array}{l}3.4(0.3) \\
3.4(0.2)\end{array}$ & $\begin{array}{c}+0.4(0.1) \dagger \\
0.0(0.1)\end{array}$ & $\begin{array}{l}+0.7(0.1)^{*} \dagger \dagger \dagger \\
-0.1(0.1)\end{array}$ \\
\hline Blood at shear rate $23 / \mathrm{s}$ & $\left\{\begin{array}{l}\text { Cold } \\
\text { Control }\end{array}\right.$ & $\begin{array}{l}5.3(0.5) \\
5.5(0.3)\end{array}$ & $\begin{array}{l}+0.8(0.3) \dagger \\
-0.4(0.1)\end{array}$ & $\begin{array}{l}+1.1(0.2)^{*}+\dagger \\
-0.3(0.3)\end{array}$ \\
\hline Plasma at shear rate $230 / \mathrm{s}$ & $\left\{\begin{array}{l}\text { Cold } \\
\text { Control }\end{array}\right.$ & $\begin{array}{l}1.4(0 \cdot 1) \\
1.4(0.1)\end{array}$ & $\begin{array}{c}0.0(0.1) \\
-0.1(0.0) \dagger\end{array}$ & $\begin{array}{l}+0.1(0.1)^{* *} \\
-0.1(0.1)\end{array}$ \\
\hline Plasma at shear rate $23 / \mathrm{s}$ & $\left\{\begin{array}{l}\text { Cold } \\
\text { Control }\end{array}\right.$ & $\begin{array}{l}2.0(0.2) \\
1.7(0.1)\end{array}$ & $\begin{array}{l}-0.1(0 \cdot 1) \\
-0.2(0 \cdot 1)\end{array}$ & $\begin{array}{c}0.0(0.1) \\
-0.2(0.1) \dagger\end{array}$ \\
\hline
\end{tabular}

Difference from control: $* \mathrm{p}<0.05 ; * * \mathrm{p}<0.01$.

$0.01 ;+++\mathrm{p}<0.001$.

Conversion: SI to traditional units-Viscosity $1 \mathrm{mPa} \mathrm{s}=1 \mathrm{cP}$

the initial blood sample. There were no significant changes in lymphocyte count or plasma fibrinogen values.

Whole blood viscosity increased in the cold by $21 \%$ at shear rates of both $230 / \mathrm{s}$ and $23 / \mathrm{s}$ (table II); this compares with increases of $6^{\circ}$ and $8^{\circ}$, that would be produced by the increase in packed cell volume alone at shear rates of 230 and $23 / \mathrm{s}$ respectively. Plasma viscosity also tended to increase at both shear rates, significantly at the higher rate, in relation to control experiments.

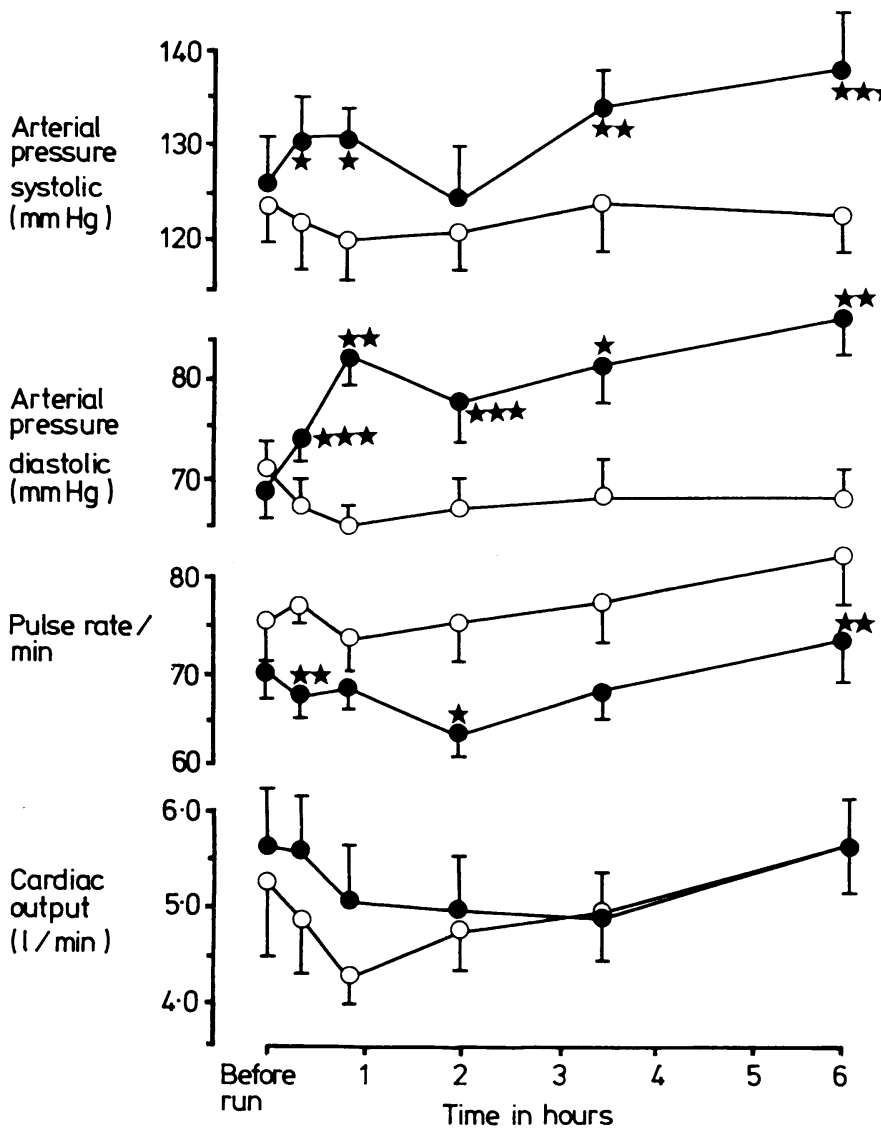

FIG 2-Arterial pressure, cardiac output, and heart rate. Open symbols represent control run. Closed symbols represent cold run. Difference from control value: ${ }^{*} \mathrm{p}<0.05{ }^{* *} \mathrm{p}<0.01 ;{ }^{* * *} \mathrm{p}<0.001$.

Arterial pressure rose on average by $12 \mathrm{~mm} \mathrm{Hg}$ systolic and $18 \mathrm{~mm} \mathrm{Hg}$ diastolic in the cold, with about a third of the increase in systolic and over half of the increase in diastolic pressure taking place in the first 20 minutes of cooling (fig 2). Pulse rate was on average lower throughout cooling than during the control run and cardiac output higher in the early part of the cold than during the control run.

Mean (SE) total plasma cholesterol concentration increased $(\mathrm{p}<0.01)$ in the cold by $0.41(0.09) \mathrm{mmol} / 1(15.8(3.5) \mathrm{mg} / 100 \mathrm{ml})$ from an initial value of $5.19(0.28) \mathrm{mmol} / \mathrm{l}(200(10 \cdot 8) \mathrm{mg} / 100 \mathrm{ml})$; of the increase, $0.08(0.05) \mathrm{mmol} / 1(3.1(1.9) \mathrm{mg} / 100 \mathrm{ml})$ occurred in the first hour. The increase was mainly in low density lipoprotein cholesterol, which increased $0 \cdot 26(0 \cdot 07) \mathrm{mmol} / 1(10 \cdot 0(2 \cdot 7) \mathrm{mg} / 100 \mathrm{ml})$ from an initial $3.22(0.16) \mathrm{mmol} / \mathrm{l}(124(6.2) \mathrm{mg} / 100 \mathrm{ml})(\mathrm{p}<0.01)$, while high density lipoprotein cholesterol increased by $0 \cdot 10(0 \cdot 03)$ $\mathrm{mmol} / 1(3.9(1.2) \mathrm{mg} / 100 \mathrm{ml})$ from $1.36(0.09) \mathrm{mmol} / \mathrm{l}(52.5(3.5) \mathrm{mg} /$ $100 \mathrm{ml})(\mathrm{p}<0.05)$. All of these increases also differed significantly $(p<0.05)$ from corresponding values in control experiments. Very low density lipoprotein cholesterol did not change significantly in the cold, nor did total triglyceride or low density, high density, or very low density lipoprotein triglyceride. Mean plasma thromboxane $B_{2}$ value did not change significantly, but was usually higher at 113 (17) $\mathrm{nmol} / 1(41.8(6.3) \mathrm{ng} / \mathrm{ml})$ at the end of cold experiments compared with $106(20) \mathrm{nmol} / 1(39 \cdot 2(7 \cdot 5) \mathrm{ng} / \mathrm{ml})$ at the end of control experiments (means and SE of eight experiments), probably due to increased production of thromboxane $A_{2}$ by virtue of the increased platelet count.

\section{Discussion}

The increases in platelet count and usually platelet volume in the cold cannot be fully explained by haemoconcentration. Increased platelet counts produced artificially by platelet infusions are in any case usually reduced rapidly ${ }^{17}$ by sequestration of platelets in the spleen. These sequestered platelets are larger on average than the circulating population and may be released by adrenaline ${ }^{17}$ - for example, in intense exercise. ${ }^{1819}$ The changes we observed might therefore be explained either by cold induced activity of sympathetic nerves releasing sequestered platelets or by production of new platelets, which are larger than older platelets. ${ }^{20}{ }^{21}$ Large platelets aggregate and adhere more readily to blood vessels ${ }^{22}{ }^{23}$ than small platelets.

Several of the other changes produced by these mild exposures to cold will tend to induce arterial thrombosis. An increase in numbers of red cells promotes platelet adhesion, probably because the presence of red cells in moving blood increases the number of impacts of platelets with the vessel wall. ${ }^{24-26}$ Increased whole blood viscosity will facilitate ultimate clotting of blood after formation of a platelet thrombus on the vessel wall; much of the increase in viscosity we observed in the cold could be explained by increases in red cells, plasma viscosity, and neutrophils but some of it might have been due to reduced red cell deformability produced by platelet activation, which reportedly increases viscosity. ${ }^{27}$

The increases in platelet and red cell counts had barely started after one hour in the cold and may not have reached their peak when the experiment ended after six hours. With additional time between the onset of a mural thrombus and death from a myocardial infarct, and between a fall in outside temperature and the resulting fall of indoor temperature, the time scale of these changes therefore accords well with the delay of roughly 24 hours between a fall in outside temperature and peak increase in mortality from coronary thrombosis. ${ }^{1}$ The longer delay of several days between a fall in outside temperature and peak increase in mortality from strokes ${ }^{1}$ may be explained by the longer delay between onset and death in cerebral thrombosis. Some difference in response is likely in the elderly, but the high incidence of cold related mortality in the elderly might be explained by their higher level of initial arterial disease, making 
them susceptible to thrombosis with changes in the blood that are harmless to fit young people.

Although intense skin cooling by ice cold water increases arterial pressure within seconds by a large reflex increase in cardiac output, ${ }^{28}$ the smaller and slower increases of arterial pressure in our experiments were largely. attributable to increased blood viscosity, particularly towards the end of the six hours when mean cardiac output was close to the control value and the increase in viscosity closely matched the increase in mean arterial pressure. Neither the increase in arterial pressure nor that in serum cholesterol that we observed in the cold would be likely to cause significant increases in arterial thrombosis within the one to three days to peak mortality after cold weather. In more prolonged cold spells the increase in cholesterol may, in any case, not persist, since serum cholesterol concentration is not generally raised in winter. ${ }^{2}$ Nevertheless, high arterial pressure, particularly systolic, as well as a raised cholesterol value that acts over months or years are well known to increase atheroma and clinical coronary heart disease. ${ }^{29-31}$ Increased arterial pressure is therefore likely to contribute to the slower effects of cold weather on coronary and cerebral thrombosis, as well as causing some rapid deaths from haemorrhage in the cold. Our results provide no indication that low density lipoproteins and total triglyceride (which are important in promoting coronary disease ${ }^{32}$ ) or high density lipoproteins (which are important in reducing coronary disease ${ }^{30}$ ) play a part in at least the early peaks in mortality in cold weather.

These results show a series of changes able to account for increased thrombosis in the cold during normal thermoregulatory adjustments to mild surface cooling at a time when core temperature was within the normal range and well above hypothermic values. This may explain the fact that mortality from coronary and cerebral thrombosis in Britain increases linearly as air temperature falls from summer to winter, ${ }^{1}$ rather than rising only in particularly cold weather as might be expected if hypothermia were responsible. The degree of cold stress in our study might readily be produced by a day's fishing in cool weather. Advice and help to elderly people to wear enough protective clothing during outdoor activities in winter, to limit the duration of such activities in cold spells, and to keep at least one small room at home at a fully comfortable temperature might produce large scale reduction in such moderate cold stresses with little restriction of activity and little expense. Measures of that kind at least seem to offer more scope for reducing cold related mortality in the elderly than do measures that are designed simply to prevent relatively rare deaths from hypothermia.

We are greatly indebted to the volunteers for their cooperation and to Dr Lawrence Youlten for advice. The work was financed by a programme grant from the Medical Research Council.

\section{References}

1 Bull GM, Morton J. Environment, temperature and death rates. Age Ageing $1978 ; 7: 210-24$

variou, Brozovic M, Chakrabarti R, et al. Relationship of air temperature to various chemical

3 Roddis LH, Cooper GW. The effect of climate on blood pressure. FAMA $1926 ; 87: 2053-5$.

4 Rose G. Cold weather and ischaemic heart disease. British fournal of Preventive and Social Medicine 1966;20:97-100.

5 Brennan PJ, Greenberg G, Miall WE, Thompson SG. Seasonal variation in

arterial blood pressure. Br Med $\mathcal{F} 1982 ; 285: 919-23$.
6 Mangum $M$, Haymes EM, Lipner $\mathrm{H}$. Coagulation and fibrinolytic responses to

7 Bazett HC, Sunderman FW, Doupe J, Scott JC. Climatic effects on the volume and composition of blood in man. Am F Physiol 1940;129:69-83

8 Glaser EM. Acclimatization to heat and cold. F Physiol (Lond) 1950;110:330-7. 9 Kalsner S. The coronary artery. London: Croom Helm, 1982:599.

ayward MG, Keatinge WR. Roles of subcutaneous fat and thermoregulatory reflexes in determining abil

11 DuBois D, DuBois EF. Clinical calorimetry. Tenth paper. A formula to estimate the approximate surface area if height and weight be known. Arch Intern Med the approximate

12 Weir JB de V. New methods for calculating metabolic rate with special reference to protein metabolism. F Physiol (Lond) 1949;109:1-9.

$13 \mathrm{Kim}$ TS, Rahn H, Farhi LE. Estimation of true venous and arterial Pco, by gas analysis of a single breath. F Appl Physiol 1966;21:1338-44.

14 Paar D. Zuverlassigkeit von fibrogenbestimmungen (Präzision) Richtigkeit und Normalwerte. Blut 1971;23:1-6.

15 Wells RE, Denton R, Merrill EW. Measurement of viscosity of biologic fluids by cone plate viscometer. F Lab Clin Med 1961;57:646-56.

16 Carlson K. Lipoprotein fractionation. $\mathcal{F}$ Clin Pathol 1973;26(suppl 5):32-7. splenic" thombocytopenia. $\mathcal{F}$ Clin Invest $1966 ; 45: 645-57$

18 Finkel A, Cumming GR. Effects of exercise in the cold on blood clotting and platelets. F Appl Physiol 1965;20:423-4.

19 Peatfield RC, Gawel MJ, Rose FC. The effects of exercise on platelet numbers and size. Fournal of Medical and Laboratory Sciences (in press).

20 McDonald TP, Odell TT, Gosslee DG. Platelet size in relation to platelet age. Proc Soc Exp Biol Med 1964;115:684-9.

21 Corash L, Shafer B, Perlow M. Heterogeneity of human whole blood platelet subpopulations. II. Use of subhuman primate model to analyse the relationship

22 Blajchman MA, Senyi AF, Hirsh J, Genton E, George JN. Hemostatic function, survival and membrane glycoprotein changes in young versus old platelets. 7 Clin Invest $1981 ; 68: 1289-94$.

23 Thompson CB, Jakubowski JA, Quinn PG, Deykin D, Valeri CR. Platelet size as a determinant of platelet function. F Lab Clin Med 1983;101:205-13.

24 Aarts PAMM, Bolhuis PA, Sakariassen KS, Heethaar RM, Sixma JJ. Red blood cell size is important for adherence of blood platelets to artery subendothelium. Blood 1983;62:214-7.

25 Bouhoutsos J, Morris T, Chavatsas D, Martin P. The influence of haemoglobin and platelet levels on the results of arterial surgery. Br $\mathcal{F}$ Surg 1974;61:984-6. 26 Turitto VT, Baumgartner HR. Platelet interaction with subendothelium in a perfusion system. Physical role of red blood cells. Microvasc Res 1975;9:335-44. Palinski W, Torsellini A, Doni L. Influence of platelet activation on erythrocyte deformability. Thromb Haemost 1983;49:84-6.

28 Keatinge WR, McIlroy MB, Goldfien A. Cardiovascular response to ice-cold showers. F Appl Physiol 1964;19:1145-50.

29 Kannel W, Gordon T, Swartz MJ. Systolic versus diastolic blood pressure and risk of coronary heart disease: the Framingham study. Am $\mathcal{X}$ Cardiol 1971 ;27: 335-46.

30 Peterssen B, Trell E, Henningen N-C, Hood B. Risk factors for premature death in middle-aged men. Br Med 7 1984;288:1264-8.

31 Heller RF, Chinn S, Tunstall Pedoe HD, Rose G. How well can we predict coronary heart disease? Findings in the United Kingdom heart disease prevention project. $\mathrm{Br}$ Med $\mathrm{F} 1984 ; 288: 1409-11$

32 Castelli WP, Doyle JT, Gordon T, et al. HDL cholesterol and other lipids in coronary heart disease. The cooperative lipoprotein phenotyping study.
Circulation 1977;55:767-72.

(Accepted 12 September 1984)

ONE HUNDRED YEARS AGO

In his able report on the Royal Lunatic Asylum at Montrose, Dr. Howden calls attention to the marked improvement in health that frequently takes place when a lunatic is removed from one asylum to another. Of nineteen male pauper patients, received into the Montrose Asylum during the last two years from other institutions, eleven gained in all $147 \mathrm{lbs}$., six lost in all $38 \mathrm{lbs}$., and two remained stationary. Of nineteen female patients of the same class, fourteen gained in all $187 \mathrm{lbs}$., four lost amongst them $20 \mathrm{lbs}$., and two remained stationary. Again, three private patients, transferred from other asylums, gained respectively 7,10 , and $41 \mathrm{lbs}$. The individual losses were in all cases trifling, and resulted from temporary illness, or increased waste entailed by work. The individual gains, on the other hand, were often remarkable. Five men gained from 20 to $41 \mathrm{lbs}$. each in twelve months; and seven women, in the same period, gained from 15 to $40 \mathrm{lbs}$. As an instance of remarkably rapid increase in weight, Dr. Howden cites the case of an imbecile, transferred from the lunatic ward of a poorhouse, who, in one month, gained 7 lbs. This increase of weight in lunatics, transferred from one establishment to another, must, Dr. Howden thinks, be due to one of two causes; either to improved diet and more healthy surroundings, or to the mere effect of change of residence. In the case of lunatics transferred from poorhouses, he is inclined to suspect that the first is the most important factor; but, in the case of other lunatics, he cannot doubt that the second cause mentioned is the more influential. If it can be shown, he argues, that in the cases of all lunatics transferred from one asylum to another, we have improvement in bodily, and perhaps also in mental condition, we have at our command a valuable, but hitherto only imperfectly recognised, means of treatment. We are all aware of the benefit some persons derive from a change of air; and there is every reason to believe that the insane derive a similar, or even greater, advantage from it.

(British Medical fournal $1884 ; \mathrm{i}: 963$. 